\title{
The major intestinal metabolites of anthocyanins are unlikely to be conjugates of their parent compounds but metabolites of their degradation products
}

\author{
Colin Kay ${ }^{1}$, Paul Kroon ${ }^{2}$ and Aedin Cassidy ${ }^{1}$ \\ ${ }^{1}$ University of East Anglia, Norwich, UK and ${ }^{2}$ Institute of Food Research, Norwich, UK
}

\begin{abstract}
Anthocyanins are a class of flavonoid that impart blue and red colour to many berries and fruits ${ }^{(1,2)}$. It has been reported that those individuals in the population who consume the highest amounts of anthocyanins are at lower risk of developing CHD and CVD relative to the lowest consumers ${ }^{(3)}$. Moreover, numerous ex vivo and in vitro experimental studies have described vascular mechanisms of action that are in keeping with protection against $\mathrm{CVD}^{(4-13)}$. However, doses of anthocyanins utilised in these studies are commonly $>10 \mu \mathrm{M}^{(5,7,8)}$, which despite a high dietary consumption of anthocyanins (doses $>500 \mathrm{mg}$ in many clinical studies ${ }^{(4,14,15)}$ ) does not appear achievable in human subjects. Furthermore, the in vitro mechanistic bioactivity of anthocyanins has been exclusively explored using aglycones and glycoside conjugates, despite a lack of evidence establishing these compounds as the biologically-available forms.

As spontaneous degradation of anthocyanins to phenolic acids and aldehydes is reported to occur under experimental ${ }^{(16)}$ and biological $^{(17,18)}$ conditions ${ }^{(17,18)}$, it is likely that degradation products of anthocyanins contribute substantially to their alleged benefits. Thus, the overall objective of the present study was to establish the chemical fate of anthocyanins and the nature of the breakdown process in the gut.

The Caco- 2 cell-culture studies indicated that after $4 \mathrm{~h}$ incubation of anthocyanins in cell-culture media (cell-free Dulbecco's modified Eagle's medium (DMEM)) $43 \%$ of the initial level of cyanidin-3-glucoside $(\mathrm{C} 3 \mathrm{G})$ and $2 \%$ of that of cyanidin remains $(P<0.0001)$. The parent anthocyanidin structure spontaneously degrades to yield protocatechuic acid (PCA) and phloroglucinaldehyde (PGA), which is confirmed in two other tested matrices (phosphate and Hank's buffers). In intestinal epithelial cell cultures (Caco-2 cells) the degradation product PCA is metabolised to sulfate and glucuronide conjugates, as indicated by both enzyme hydrolysis (sulfatase and glucuronidase treatment) and MS (m/z; PCA 155, sulfate 235, glucuronide 331; cyanidin 287, sulfate 367, glucuronide 463). All values are expressed relative to cell-free incubations, controlled for temperature, time, $\mathrm{pH}$ and extraction procedure across nine replicates for each of DMEM and Hank's buffer.

It is difficult to establish whether PGA contributes equally to the metabolite pool as its recovery in cultured cell media and cell-free DMEM is extremely low $(13 \%$ and $26 \%$ respectively; $P<0.0001)$. Additionally, the exact extent of sulfation and glucuronidation is difficult to establish as treatment with sulfatase and glucuronidase resulted in deglycosylation of C3G, and subsequent degradation of the aglycone results in the formation of new degradation products. It is, however, clear that degradation and recovery are major concerns in anthocyanin analysis.

These data suggest that the major intestinal metabolites of anthocyanins are unlikely to be conjugates of the parent compounds, but metabolites of their degradation products. Thus, efforts to establish the biological activities of anthocyanins must be re-established using the phenolic acid and aldehyde products of degradation, along with their respective metabolites.
\end{abstract}

1. Wu X, Beecher GR, Holden JM, Haytowitz DB, Gebhardt SE \& Prior RL (2006) J Agric Food Chem 54, 4069-4075.

2. Clifford MN (2000) J Sci Food Agric 80, 1063-1072.

3. Mink PJ, Scrafford CG, Barraj LM et al. (2007) Am J Clin Nutr 85, 895-909.

4. Erdman JW Jr, Balentine D, Arab L et al. (2007) J Nutr 137, 718S-737S.

5. Kamata K, Makino A, Kanie N et al. (2006) J Smooth Muscle Res 42, 75-88.

6. Bell DR \& Gochenaur K (2006) J Appl Physiol 100, 1164-1170.

7. Mendes A, Desgranges C, Chèze C, Vercauteren J \& Freslon JL (2003) Fundam Clin Pharmacol 17, 673-681.

8. Andriambeloson E, Magnier C, Haan-Archipoff G et al. (1998) J Nutr 128, 2324-2333.

9. Galvano F, La Fauci L, Lazzarino G et al. (2004) J Nutr Biochem 15, 2-11.

10. Pergola C, Rossi A, Dugo P, Cuzzocrea S \& Sautebin L (2006) Nitric Oxide 15, 30-39.

11. Rossi A, Serraino I, Dugo P et al. (2003) Free Radic Res 37, 891-900.

12. Rechner AR \& Kroner C (2005) Thromb Res 116, 327-334.

13. Xia M, Ling W, Zhu H et al. (2007) Arterioscler Thromb Vasc Biol 27, 519-524.

14. Kay CD, Mazza GJ \& Holub BJ (2005) J Nutr 135, 2582-2588.

15. Kroon PA, Clifford MN, Crozier A et al. (2004) Am J Clin Nutr 80, 15-21.

16. Sadilova E, Stnintzing FC \& Carle R (2006) J Food Sci 71, 504-512.

17. Aura AM, Martin-Lopez Pilar, O'Leary KA et al. (2005) Eur J Nutr 44, 133-142.

18. Vitaglione P, Donnarumma G, Napolitano A et al. (2007) J Nutr 137, 2043-2048. 